\begin{tabular}{|c|c|c|}
\hline \multirow[t]{2}{*}{$\underline{\mathrm{DE}}$} & \multirow[t]{2}{*}{$\begin{array}{l}\text { DE GRUYTER } \\
\text { OPEN }\end{array}$} & ECONOMIC THEMES (2015) 53 (3): 331-342 \\
\hline & & DOI 10.1515/ethemes-2015-0019 \\
\hline
\end{tabular}

\title{
SECTORAL STATE AID IN THE EUROPEAN UNION AND THE WESTERN BALKAN COUNTRIES
}

\author{
Boban Stojanović \\ University of Niš, Faculty of Economics, Serbia \\ $\bowtie$ dr.boban.stojanovic@gmail.com \\ Tanja Stanišić \\ University of Kragujevac, Faculty of Tourism and Hospitality \\ in Vrnjačka Banja, Serbia \\ $\bowtie$ tanja.stanisic@gmail.com \\ UDC \\ 338.246.027 \\ (4-672EU+4-12) \\ Review paper \\ Received: \\ 10.11.2014 \\ Accepted: \\ 24.9.2015

\begin{abstract}
State aid aimed to certain market participants, especially some of its categories, carries a risk of distortion of competition. Therefore, it is necessary to control allocation of state aid and its direction from the sectoral objectives towards more justified horizontal objectives of allocating. This paper examines the practice of assigning sectoral state aid in the European Union and in the selected Western Balkan countries by using the methods of comparative and correlation analysis. The aim is to identify deviations and point out to the preferred ways of state aid allocation.
\end{abstract} \\ Keywords: sectoral state aid, European Union, Western Balkan

\section{Introduction} \\ At the level of the European Union (EU), the state aid granting is adequately \\ regulated by a number of regulations and rules. Due to the great importance of \\ the issues, rules and regulations are constantly improving. In the European \\ developing countries, which are not yet members of the EU, the requirements \\ for developing a functional system of state aid control have emerged during the \\ last decade (Stojanović, Stanišić, 2011, p. 46). A long-time development of the \\ system of state aid control of the European Union has led to the establishment \\ of appropriate patterns and rules in the allocation of each specific category of \\ state aid. The main objective of the established rules is the greater expediency
}


of the use of state aid granted, with the least possible distortion of competition in the market. The EU responds to this aim, which is often promoted by the phrase "less and better targeted state aid" (European Commission, 2005). Serbia and the other Western Balkan countries have to design and develop its own systems of state aid control in a way that will be more focused on aligning practice of granting state aid with the EU criteria.

The three main categories of state aid are horizontal, regional and sectoral state aid. Given that sectoral state aid is aimed to a predetermined or known user in certain sectors and activities, this form of state aid is considered the least justified and carries the greatest risk of distortion of competition (Stojanović et al, 2014, p. 90). Therefore, the objective of institutions for the state aid control is less its share in total aid. The purpose of the research presented in this paper is to assess the extent and trend of allocation of sectoral state aid in the European Union and the Western Balkan countries. The aim is to identify deviations in the Western Balkan countries in relation to the practice of the European Union.

Considering the purpose and objective of the research, each segment of the paper explores trends of state aid on the European Union level and in the selected Western Balkan countries. In this way, comparative analysis and identifying of deviations are enabled. The lack of relevant data for Macedonia and Bosnia and Herzegovina (due to the lack of development of the system of state aid control), the group of Western Balkan countries is limited to three countries - Serbia, Croatia and Montenegro. The research includes data up to 2012 (latest available data on state aid granted are for 2012) and Croatian therefore was not included in the group of the European Union countries. Croatia became a member of the European Union in July 2013.

\section{About the Main Categories of State Aid}

The main classification of state aid is a classification of horizontal, regional and sectoral state aid. Each of the main categories of state aid covers a wide range of objectives to which state aid is aimed.

Horizontal state aid is intended for all firms in an economy, not for selected and predetermined sectors and regions. It is considered as category of state aid that has the least destructive impact on the conditions of competition. State aid that is allocated horizontally to all sectors is less selective than other forms of state aid. Hence, the prevailing opinion is that the positive effects of horizontal state aid and its contribution to solving the market failure is much higher than its negative impact on competition. It is often argued that the horizontal state aid effectively correct the market failure and contributes to the growth of social welfare (Kesner - Škreb, 2011, p. 1). These are the reasons why the authorities 
responsible for the state aid control are trying to impose rules that would redirect state aid from sectoral to horizontal. Any increase in the percentage share of horizontal state aid in the overall structure of aid is seen as a positive trend.

Horizontal state aid is aimed to: research and development (R\&D); environmental protection; small and medium business enterprises (SMEs); rescue and restructuring of business entities in difficulty; employment; training; culture; provision of venture capital. The aim of regulation of horizontal state aid is a balance between the clearly specified objectives of great importance and danger that the state, in desire for its realization, distorts competition in the market. Horizontal state aid is aimed to the objectives for which the clear benefits of state intervention are usually evident (Wishlade, Michie, 2009, p. 24). Nevertheless, the control of this type of state aid details the amount of state aid which can be approved, to which projects, under what conditions and what kind of development policies in particular should be supported in order to maximize the positive effects (Flam, 2008, p. 1).

The fact that the horizontal state aid is not aimed to predetermined sectors or regions and its availability to a greater number of business entities make it less selective compared to the other two categories of state aid. Because of that, this category of aid has fewer possibilities for distortion of competition. Horizontal state aid is focused on the goals that are the backbone of sustainable economic development of the country (research, development and innovation, small and medium enterprises), or this type of aid is in the function of support and promotion often marginalized development goals (environment, education, employment of disadvantaged or disabled persons).

The aim of granting of regional state aid is encouraging economic development of underdeveloped or less developed regions. A special motive for directing state aid to certain regions is the extremely low standard of living and high unemployment. Regional state aid can be used to avoid the concentration of production in some parts of the country and thus stimulate economic development of poor regions. This category is aimed to business entities in regions where investments are considered justified because of a range of economic, natural, social, demographic and/or other deficiencies. This category includes state aid measures for stimulating economic activity and thus contribute to the reduction or elimination of regional imbalances and, in many countries, records a significant amount (Wishlade, 2008, p. 754). Regional state aid focuses on handicaps of threatened and less developed regions. This geographical specificity makes a difference between regional aid and other forms of horizontal aid, such as aid for research, development, innovation, employment, environmental protection (European Commission, 2006, p. 13).

Regional state aid includes three basic categories: regional investment state aid, regional state aid for newly created small enterprises and operational 
regional state aid. It should be noted that the first form of regional state aid requires special vigilance and control. Large investments carry the risk that the amount of aid exceeds the minimum required in order to compensate the regional disadvantages. There is also the danger that state aid for these projects leads to distorted effects, such as inefficient location choices and greater distortion of competition. In addition, aid is an expensive transfer of funds from taxpayers to the aid recipients. There may be a net loss of welfare, a situation in which the costs exceed the benefits for consumers and producers (European Commission, 2009, p. 3). Hence, it is necessary a deeper and more comprehensive analysis of state aid for large investment projects.

In most European countries, regional state aid is granted within a sector defined budget, taking into account the criteria of regional development when providing aid, on the basis of regional development programs. In addition to funds from the budget of the Republic of Serbia and local government budgets, a significant source of regional aid in Serbia were donations of international institutions and donor countries (Government of the Republic of Serbia, 2006, p. 106). In the future, the EU funds will represent the most important source of international aid for regional development in Serbia.

Sectoral state aid is intended to predetermined or known business entities in certain industries or sectors. Sectoral state aid carries a greater potential risk of distortion of competition in relation to the horizontal aid, due to the highly selective nature. Also, this form of state aid is not aimed at correcting market failures. Very often, this type of aid only postpones the necessary radical changes and structural adjustments in certain sectors and industries. Therefore, the temporary nature of sectoral state aid is necessary for its positive effects. However, there is encouraging that this form of state aid is often transformed, under the pressure of users, from temporary into permanent. A particular danger is the allocation and concentrating sectoral state aid to a small number of companies. This method of its allocation easily leads to the risk of moral hazard and to a situation where companies expect help from the state whenever are in difficulties. This kind of aid can create an unnatural competitive advantage and put low-productivity sectors in a privileged position at the expense of other sectors of the economy.

All above mentioned, in addition to a pronouncedly destructive effect on competition, may have a very negative impact on the efficiency of the overall economy. There are some opinions that sectoral state aid, by favouring one, usually less efficient enterprises, reduces social welfare (Kesner - Škreb, 2011, p. 1).

Each type of state aid (horizontal, regional or sectoral) can be granted on one of three ways: as a state aid scheme, as an individual state aid and on an ad hoc basis. 


\section{Methodological Framework of Research}

The purpose of this research is the identification of trends in sectoral state aid granted on the EU level, in Serbia and in the selected Western Balkan countries. The aim is to identify variations in sectoral state aid granted in these countries in relation to the EU practice. The basic premise of the research is the existence of significant variations in the practice of granting state aid in the Western Balkan countries in relation to the positive experience of the European Union.

The following methods are used in the research: comparative analysis (with using graphical method for presenting the results of the comparative analysis), descriptive statistics and correlation analysis. Comparative analysis and descriptive statistics are used to identify deviations of sectoral state aid in Serbia and in selected countries in the region in relation to the EU member states. Correlation analysis examines the interdependence between sectoral state aid and the gross domestic product (GDP) in the analysed groups of countries.

Several databases represent the information base of research. For information on the sectoral state aid in the EU Member States, information base is the base of the European Commission. Reports of authoritative bodies: the Commission for State Aid Control of the Republic of Serbia (Reports on state aid granted in the Republic of Serbia 2006 - 2012), the Commission for State Aid Control of Montenegro (Annual Reports on State aid granted in Montenegro 2007 - 2012) and the Croatian Competition Agency (Annual report on State Aid 2006 - 2012) are an information base on sectoral state aid granted in the countries in the region. For GDP data base is Eurostat.

The research covers the period from 2006 to 2012. The reason for choosing this period is to provide a comparative analysis between the EU countries and selected countries in the region. Reports on state aid granted in Serbia and Montenegro are available starting from 2006.

\section{Research Results}

Sectoral state aid is intended to precisely defined activities and sectors, disturbing or threatening to distort competition in the market to a greater extent. Because of the selectivity of this kind of aid, especially when it comes to socalled steel, coal, shipbuilding and synthetic fibre sectors, the EU applies special rules. Given the above mentioned, these rules are embedded in special protocols of the Stabilisation and Association Agreement (Stojanovic et al, 2013, p. 168). Hence, it would be logical to expect that the analysed countries in the region follow the efforts of the European Union to the low participation of sectoral state aid in the overall structure of aid. 
Table 1 shows the percentage share of sectoral state aid in total aid in the EU Member States in the seven-year period (2006 - 2012), as well as the participation of sectoral state aid at the EU level as a whole.

Table 1 Sectoral State Aid as \% of Total State Aid in the EU Member States (2006 - 2012)

\begin{tabular}{|c|c|c|c|c|c|c|c|c|c|}
\hline & \multicolumn{8}{|c|}{ Sectoral state aid as \% of total state aid } & \multirow{2}{*}{ 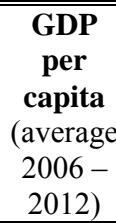 } \\
\hline & 2006 & 2007 & 2008 & 2009 & 2010 & 2011 & 2012 & $\begin{array}{c}\text { Average } \\
2006 \text { - } \\
2012\end{array}$ & \\
\hline Austria & 9.64 & 16.49 & 12.75 & 30.28 & 9.60 & 11.71 & 10.48 & 20.15 & 33,943 \\
\hline Belgium & 6.92 & 24.80 & 23.06 & 20.12 & 14.60 & 22.24 & 15.34 & & 32,300 \\
\hline Bulgaria & 20.61 & 86.89 & 93.95 & 84.03 & 49.65 & 45.68 & 59.58 & .91 & 4,586 \\
\hline Cyprus & 20.55 & 46.95 & 32.89 & 64.72 & 27.50 & 20.72 & 27.12 & 34.35 & 20,771 \\
\hline $\begin{array}{c}\text { Czech } \\
\text { Republic }\end{array}$ & 27.89 & 21.37 & 25.65 & 34.47 & 35.50 & 20.48 & 18.19 & 26.22 & 13,771 \\
\hline Denmark & 17.95 & 18.66 & 15.10 & 2.45 & 1.02 & .91 & 12.69 & .97 & 42,129 \\
\hline Estonia & 68.63 & 71.71 & 66.02 & 72.48 & 65.80 & 61.99 & 47.67 & 64.90 & 11,471 \\
\hline Finland & 72.16 & 71.37 & 63.27 & 61.75 & 62.04 & 43.80 & 47.03 & 60.20 & 33,786 \\
\hline France & 76.63 & 23.28 & 34.98 & 30.52 & 29.63 & 14.80 & 30.75 & 34.37 & 29,871 \\
\hline Germany & 21.24 & 22.90 & 19.49 & 16.50 & 19.82 & 21.79 & 22.12 & 20.55 & 30,243 \\
\hline Greece & 49.72 & 46.61 & 40.24 & 41.34 & 12.06 & 16.21 & 17.27 & 31.92 & 19,457 \\
\hline Hun & 62.50 & 67.68 & 36.02 & 30.95 & 61.04 & 43.06 & 26.23 & 46.78 & 9,671 \\
\hline Ireland & 33.68 & 44.86 & 63.20 & 55.07 & 48.38 & 43.81 & 33.29 & 46.04 & 38,071 \\
\hline Italy & 38.03 & 37.62 & 34.58 & 28.59 & 26.47 & 28.08 & 29.01 & 31.77 & 25,771 \\
\hline Latvia & 87.89 & 35.37 & 65.74 & 83.11 & 58.25 & 66.89 & 17.00 & 59.18 & 9,314 \\
\hline Lithuania & 59.27 & 74.28 & 64.84 & 51.58 & 47.22 & 41.83 & 43.12 & 54.59 & 9,271 \\
\hline Luxembourg & 42.09 & 35.11 & 24.69 & 16.46 & 20.89 & 20.75 & 23.30 & 26.19 & 76,557 \\
\hline Malta & 97.04 & 96.07 & 97.19 & 77.24 & 76.39 & 61.51 & 71.12 & 82.37 & 14,800 \\
\hline Netherlan & 31.92 & 40.56 & 38.01 & 34.46 & 31.04 & 28.79 & 30.05 & 33.55 & 35,129 \\
\hline Poland & 55.06 & 41.06 & 52.13 & 46.56 & 39.03 & 46.57 & 40.17 & 45.80 & 8,800 \\
\hline Portugal & 87.36 & 88.82 & 81.92 & 80.90 & 65.42 & 73.46 & 43.37 & 74.46 & 15,900 \\
\hline Romania & 79.53 & 92.38 & 81.84 & 88.96 & 53.73 & 41.19 & 32.43 & 67.15 & 6,043 \\
\hline Slovakia & 28.17 & 37.75 & 33.26 & 35.58 & 22.05 & 9.86 & 23.34 & 27.14 & 11,443 \\
\hline Slovenia & 42.79 & 47.57 & 37.75 & 28.48 & 27.69 & 20.87 & 14.68 & 31.40 & 17,200 \\
\hline Spain & 43.34 & 44.60 & 34.10 & 29.85 & 32.23 & 37.64 & 35.86 & 36.80 & 22,900 \\
\hline Sweden & 12.63 & 11.85 & 10.29 & 15.35 & 8.92 & 8.04 & 7.74 & 10.69 & 37,200 \\
\hline $\begin{array}{c}\text { United } \\
\text { Kingdom }\end{array}$ & 28.81 & 29 & 25.11 & 20.08 & 18.24 & 21.18 & 17.06 & 97 & 29,814 \\
\hline EU-27 & 49.81 & 34.22 & 32.74 & 29.81 & 27.85 & 25.05 & 26.10 & 32.23 & 24,743 \\
\hline
\end{tabular}

Source: European Commission,

http://ec.europa.eu/competition/state_aid/studies_reports/studies_reports.html, Eurostat, http://appsso.eurostat.ec.europa.eu/nui/submitViewTābleAction.do

\footnotetext{
${ }^{1}$ Data on sectoral state aid includes state aid for agriculture and fisheries sector.
} 
At the level of the EU as a whole, there was a reduction of sectoral state aid by $17.5 \%$ in the observed period, so that the participation of sectoral state aid (including aid to agriculture and fisheries) in the total amount of aid was $26.10 \%$ in 2012. Among the individual EU countries, the greatest decrease in 2012 compared to 2006 was recorded in: Romania (-47\%), France (-45\%), and Portugal (-44\%).

Figure 1 shows that the only three countries (Bulgaria, Cyprus and Germany) have recorded an increase in the share of sectoral state aid. In addition, the increase in the two countries is not alarming (Cyprus has recorded an increase of about $6.5 \%$, and Germany of $0.88 \%$ in the reporting period).

Figure 1 Sectoral State Aid as \% of Total State Aid in the EU Member States in 2006 and 2012

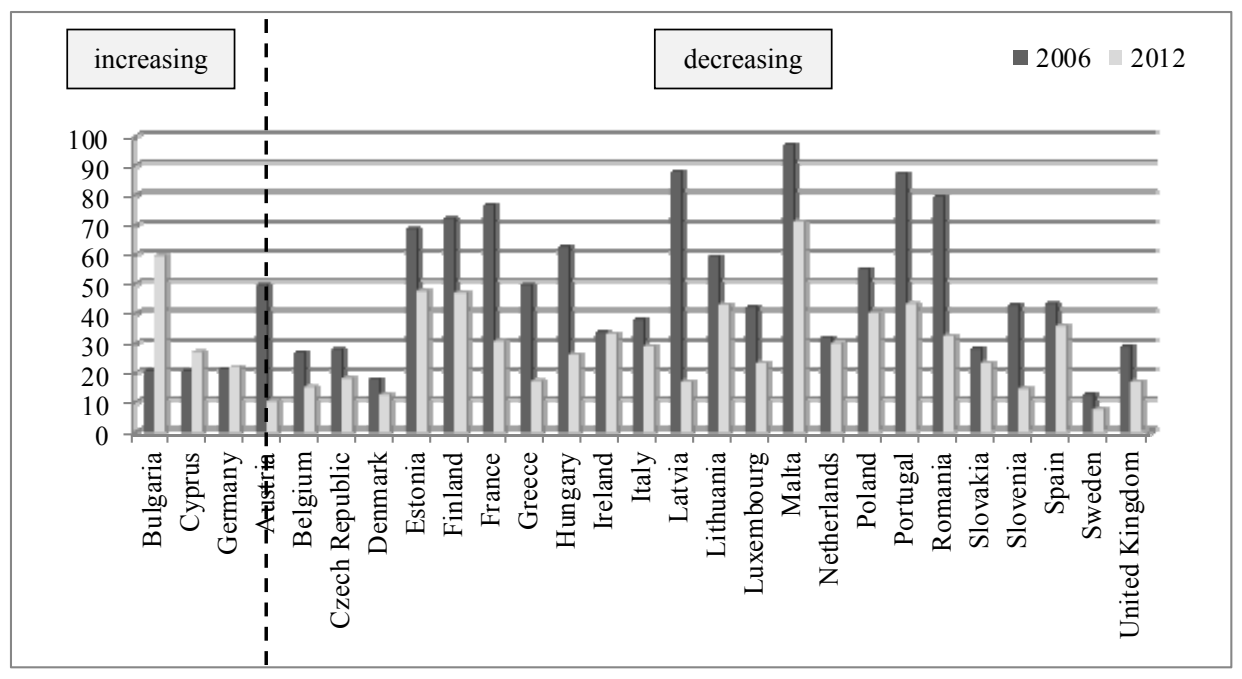

Source: European Commission,

http://ec.europa.eu/competition/state_aid/studies_reports/studies_reports.html

Table 2 gives an overview of the share of sectoral state aid in total aid in Serbia, Croatia and Montenegro in the period from 2006 to 2012. State aid for agriculture in official reports on state aid in Serbia, Croatia and Montenegro is shown apart from sectoral state aid, because it does not carry the risk of significant distortions of competition. In order to compare data presented in Table 2 with the data for the European Union countries, we included data on state aid intended for agriculture (and fisheries) in the sectoral state aid. Also, there are divided opinions on whether state aid for rescuing and restructuring should be classified as sectoral or horizontal state aid. At the EU level, this form of state aid is part of sectoral state aid. In the analysed Western Balkan countries, this form of aid is part of horizontal state aid. In order to enable 
comparative analysis, we included state aid for rescuing and restructuring in the data on sectoral state aid in Table 2.

Table 2 Sectoral State Aid as \% of Total State Aid in Serbia, Croatia and Montenegro (2006 - 2012)

\begin{tabular}{|c|c|c|c|c|c|c|c|c|c|}
\hline & \multicolumn{8}{|c|}{ Sectoral state aid as \% of total state aid } & \multirow{2}{*}{$\begin{array}{c}\text { GDP } \\
\text { per capita } \\
\text { (average } \\
2006- \\
2012 \text { ) } \\
\end{array}$} \\
\hline & 2006 & 2007 & 2008 & 2009 & 2010 & 2011 & 2012 & $\begin{array}{c}\text { Prosek } \\
2006 \text { - } \\
2012^{2}\end{array}$ & \\
\hline Serbia & - & - & 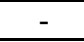 & - & 56.4 & 48.9 & 60.5 & 55.27 & 3,957 \\
\hline Croatia & 85.81 & 84.73 & 79.86 & 86.79 & 87.6 & 85.91 & 81.98 & 84.67 & 10,214 \\
\hline Montenegro & 48.07 & 43,22 & 46.60 & 95.83 & 98.01 & 92.52 & 86.00 & 77.84 & 4,725 \\
\hline
\end{tabular}

Source: http://www.mfp.gov.rs/, http://www.kkdp.me/, http://www.aztn.hr/, http://appsso.eurostat.ec.europa.eu/nui/submitViewTableAction.do

Given the fact that the average share of sectoral state aid at the EU level for the period from 2006 to 2012 amounted $32.23 \%$, it can be noted that its share in the countries in the region is above that average. Serbia recorded the lowest share in 2012 (60.5\%), while the share of sectoral state aid in total aid in Croatia and Montenegro was at a very high level, $85.91 \%$ and $92.52 \%$, respectively.

Figure 2 Sectoral State Aid as \% of Total State Aid in Serbia (2010 and 2012), Croatia and Montenegro (2006 and 2012)

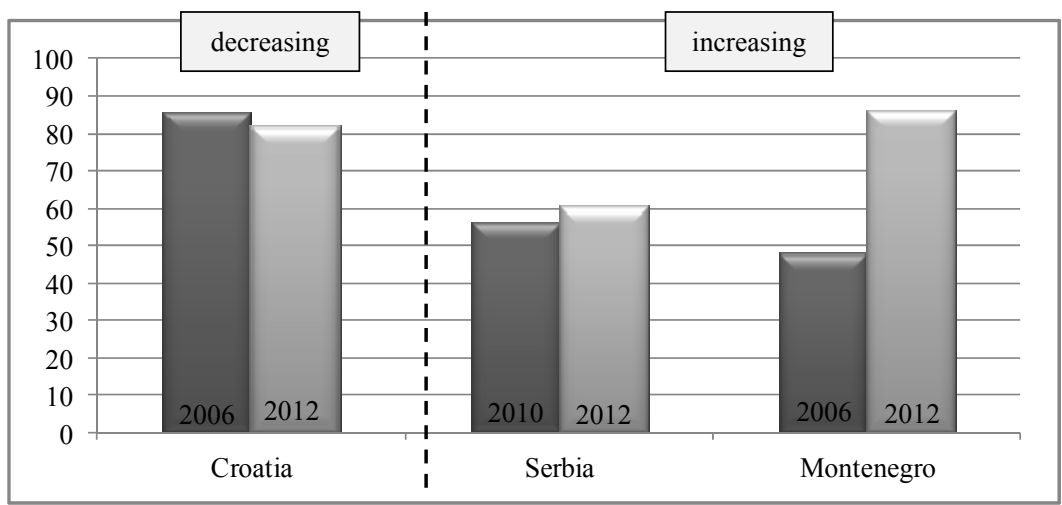

Source: http://www.mfp.gov.rs/, http://www.kkdp.me/, http://www.aztn.hr/

Figure 2 shows that only in Croatia there was a slight decrease in the share of sectoral state aid in 2012 compared to 2006, while Montenegro recorded an

\footnotetext{
${ }^{2}$ Reports for Serbia until 2010 do not include data on state aid granted in the agriculture, hunting, forestry and fisheries sector. Therefore, the average value of sectoral state aid for Serbia is calculated on the basis of available data from the three-year period $(2010-2012)$.

${ }^{3}$ The data for Serbia are available starting from 2010.
} 
increase. Reports for Serbia until 2010 do not include data on state aid granted in the agriculture, hunting, forestry and fisheries sector. For this reason we perceived change of participation of sectoral state aid in Serbia in 2012 compared to 2010. Also, there was an increase. Thus, the analysed countries in the region do not follow the recommendations and tendencies of the European Union to the low participation of sectoral state aid in the overall structure and increasing share of horizontal aid.

Figure 3 shows the trend of sectoral state aid in the European Union, Serbia, Croatia and Montenegro.

Figure 3 Trend of Sectoral State Aid as \% of Total State Aid in the EU and the Analysed Countries in the Region (2006 - 2012)

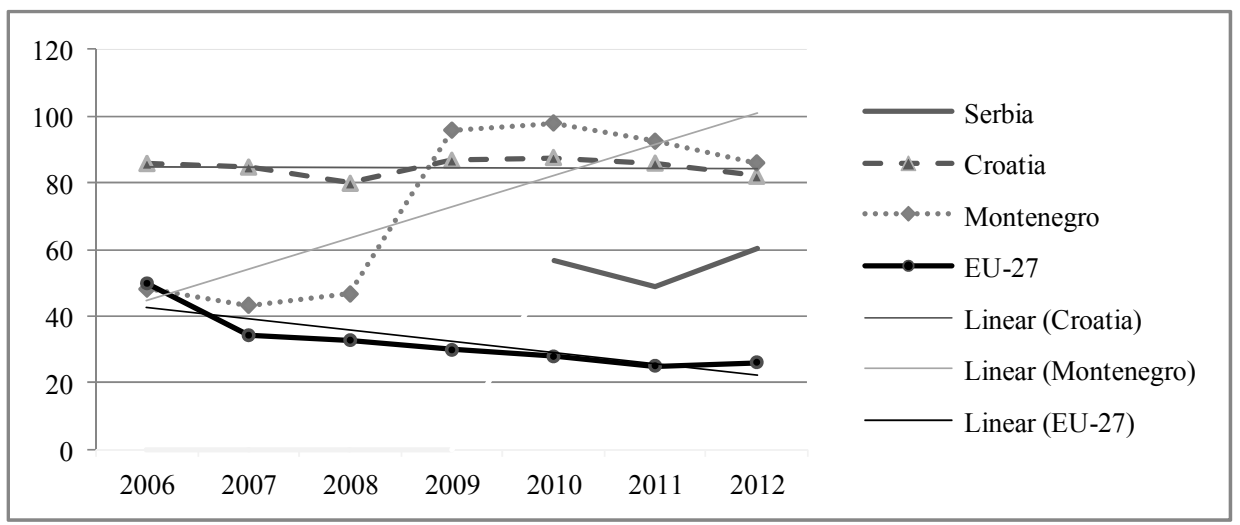

Source: http://ec.europa.eu/, http://www.mfp.gov.rs/, http://www.kkdp.me/, http://www.aztn.hr/

The declining trend line is characterized for allocation of sectoral state aid in the EU. Montenegro has an increasing trend line of share of sectoral state aid. Straight line of linear trend of sectoral state aid is characteristic of Croatia in the reporting period. However, the share of sectoral state aid in total in Croatia is at a very high level during the whole period (between 80 and 90 percent). In Serbia, there is also increasing trend of participation of sectoral state aid.

Results of descriptive statistics presented in Table 3 indicate significant deviation of the analysed countries in the region in relation to the practice of the EU Member States, particularly with regard to the minimum and mean values of percentage share of sectoral state aid. The lowest recorded share of sectoral state aid is $10.69 \%$ in the EU and $55.27 \%$ in the analysed countries in the region. The mean value of percentage share of sectoral state aid in the EU countries is $40.23 \%$, while the mean value in the group of the analysed countries in the region is $70.94 \%$. The calculated value of the coefficient of variation indicates a greater heterogeneity of the EU countries according to this criterion (partly due to the fact that there are certain countries that have 
extremely low allocations for sectoral state aid) in relation to the group of countries in the region.

Table 3 Results of Descriptive Statistics for the EU Countries and the Group of Analysed Countries in the Region (According to the Sectoral State Aid as \% of Total Aid - The Average Value for the Period 2006 - 2012)

\begin{tabular}{|c|c|c|c|c|c|c||}
\hline & $\mathrm{N}$ & Minimum & Maximum & Mean & $\begin{array}{c}\text { Std. } \\
\text { Deviation }\end{array}$ & $\begin{array}{c}\text { Variation } \\
\text { Coefficient }\end{array}$ \\
\hline EU countries & 27 & 10.69 & 82.37 & 40.2374 & 19.44612 & 48.32 \\
\hline $\begin{array}{c}\text { Countries in the } \\
\text { region }\end{array}$ & 3 & 55.27 & 84.67 & 70.9433 & 14.79636 & 20.85 \\
\hline
\end{tabular}

The values of the Pearson's correlation coefficient between the percentage share of sectoral state aid in total aid and GDP per capita in the EU and in the analysed countries in the region are given in Table 4.

Table 4 Pearson's Correlation Coefficient between Sectoral State Aid and GDP Per Capita in the EU and in the Countries in the Region (Average Values for the Period 2006 - 2012)

\begin{tabular}{||c|l|r|r||}
\hline \multicolumn{2}{|||}{} & GDP (EU) & $\begin{array}{c}\text { GDP (Countries } \\
\text { in the region) }\end{array}$ \\
\hline \multirow{3}{*}{ Sectoral state aid (EU) } & Pearson Correlation & $\mathbf{- 0 . 5 3 6 ( * * )}$ & \\
\cline { 2 - 4 } & Sig. (2-tailed) & 0.004 & \\
\cline { 2 - 4 } & N & 27 & $\mathbf{0 . 8 6 5}$ \\
\hline \multirow{3}{*}{$\begin{array}{c}\text { Sectoral state aid } \\
\text { (Countries in the region) }\end{array}$} & Pearson Correlation & & 0.334 \\
\cline { 2 - 4 } & Sig. (2-tailed) & & 3 \\
\cline { 2 - 5 } & N & & \\
\hline \hline
\end{tabular}

${ }^{* *}$ Correlation is significant at the level 0.01 .

The existence of a moderate negative correlation between the observed variables in the EU Member States (the value of the coefficient of -0.536) indicates that more developed EU countries (countries with higher levels of GDP per capita) re-orient its state aid from specific sectors to the objectives of granting horizontal state aid identified as the backbone of sustainable growth and development. The calculated value of the correlation coefficient is statistically significant. The reverse tendency is observed in the countries of the region. The country with the highest level of GDP per capita (Croatia) has the highest allocations for sectoral state aid, followed by Montenegro (which is the second country by size of GDP per capita). Serbia is on the third place according to both criteria. Hence, there is high positive correlation between the observed variables (correlation coefficient of 0.865 ).

\section{Conclusion}


The goal of establishing national systems of controlling state aid is harmonization with the European standards and practices. The basic idea of the European system of state aid control is "less and better targeted state aid". This, among other things, means a smaller share of sectoral state aid in total aid. However, analysis of the trend in the level of sectoral state aid showed that establishing a system of control in Serbia (as well as in Croatia and Montenegro) has not led to a reduction of the level of sectoral state aid. The percentage share of sectoral state aid in in the structure of total aid is significantly above the EU average. Significant deviations from the EU practices is recorded also in the analysis of the correlation between sectoral state aid and GDP in the European Union countries in relation to the group of the Western Balkan countries.

Sectoral state aid is intended for predetermined business entities in certain industries or sectors, and carries a greater potential risk of distortion of competition in relation to the horizontal state aid, due to the highly selective nature. At EU level, there was a reduction of its share in total aid, as well as the existence of a moderate negative correlation between sectoral state aid and GDP per capita. Completely the opposite tendency is noted in Serbia, Croatia and Montenegro. This suggests that state aid in Serbia, as well as in the analysed countries in the region, has no role in the achievement of goals that can be the backbone of sustainable growth and development. State aid is still the instrument of rescuing inefficient enterprises in certain sectors.

Changes of systems of state aid control in the Western Balkan countries in accordance with the EU rules and policy which promotes "less and better targeted state aid" are necessary. Accordingly, it is necessary to reduce sectoral state aid and its orientation towards horizontal objectives. Given the still large amount of sectoral state aid and state aid for rescuing and restructuring, which unjustly maintains inefficient enterprises in the life, the effectiveness of the use of state aid is still questionable. State aid in the Western Balkan countries is an unused instrument which in the future may be involved in achieving the important goals of economic prosperity. Coordinated and planned use of state aid will be necessary to achieve dynamic development in the future.

\section{References}

Agencija za zaštitu tržišnog natjecanja Republike Hrvatske, http://www.aztn.hr/onama/23/godisnja-izvjesca. Accessed 21 September 2014.

European Commission, http://ec.europa.eu/competition/state_aid/studies_reports/ studies_reports.htm. Accessed 18 October 2014.

European Commission. (2005) "State Aid Action Plan: Less and better targeted state aid: a roadmap for state aid reform 2005-2009", Consultation document. 
European Commission. (2006) "Guidelines on National Regional Aid for 2007-2013", Official Journal of the European Union (2006/C 54/08).

European Commission. (2009) "Communication from the Commission concerning the criteria for an in-depth assessment of regional aid to large investment projects", Official Journal of the European Union (2009/C 223/02).

Eurostat, http://appsso.eurostat.ec.europa.eu/nui/submitViewTableAction.do. Accessed 23 October 2014

Flam, K. (2008) "EU Environmental State Aid Policy - Wide Implications, Narrow Participation?", CANES Working Paper, Fridtjof Nansen Institute, http://www.fni.no/doc\&pdf/FNI-R1308.pdf. Accessed 13 September 2014.

Kesner - Škreb, M. (2011) „Industrial Policy and State Aid in Croatia“, Newsleter, An Occasional Publication of Institute of Public Finance, 55: 1-7.

Komisija za kontrolu državne pomoći Republike Crne Gore, http://www.kkdp.me/index.php?IDSP=217\&jezik. Accessed 21 August 2014.

Ministarstvo finansija i privrede Republike Srbije, http://www.mfp.gov.rs/pages/issue.php? $\mathrm{id}=7322$. Accessed 21 September 2014.

Stojanović, B., Stanišić, T. (2011) „Sistem kontrole državne pomoći u Srbiji - ekonomski izazovi i ograničenja“, Kontrola državne pomoći u srbiji i Evropskoj uniji, Beograd: Pravni fakultet, p. $46-62$.

Stojanović, B., Stanišić, T., Radivojević, V. (2013) "State Aid Control: Theoretical Aspects and Empirical Evidences“, Facta Universitatis, Series: Economics and Organization, $10(2): 165-177$.

Stojanović, B., Stanišić, T., Radivojević, V. (2014) „Efekti institucionalizacije državne pomoći u Republici Srbiji”, Institucioanlne promene kao determinanta privrednog razvoja Srbije, Kragujevac: Ekonomski fakultet, p. 85 - 104.

Wishlade F.G. (2008) "Competition and Cohesion - Coherence or Conflict? European Union Regional State Aid Reform Post-2006”, Regional Studies, 42 (5): 753-765.

Wishlade, G. F., Michie, M. (2009) "Pandora's Box and the Delphic Oracle: EU Cohesion Policy and State Aid Compliance", IQ-Net Thematic paper 24 (2), European Policies Research Centre.

Влада Републике Србије, Стратегија регионалног развоја Републике Србије за период од 2007. до 2012. године, http://www.srbija.gov.rs/vesti/dokumenti_ sekcija.php?id=45678. Accessed 29 September 2014.

\section{SEKTORSKA DRŽAVNA POMOĆ U EVROPSKOJ UNIJI I NEKIM ZEMLJAMA ZAPADNOG BALKANA}

Apstrakt: Državna pomoć namenjena određenim subjektima na tržištu, a posebno pojedine njene kategorije, nosi opasnost narušavanja konkurencije. Zbog toga je neophodna kontrola dodeljivanja državne pomoći i njeno usmeravanje od sektorskih ka opravdanijim horizontalnim ciljevima dodeljivanja. U radu se primenom metoda komparativne i korelacione analize ispituje praksa dodeljivanja sektorske državne pomoći u Evropskoj uniji i 
odabranim zemljama Zapadnog Balkana. Cilj je identifikovanje odstupanja i ukazivanje na poželjne pravce usmeravanja državne pomoći.

Ključne reči: sektorska državna pomoć, Evropska unija, Zapadni Balkan 